\title{
A Form of One's Own: Virginia Woolf's Art of the Portrait Essay · Jocelyn Bartkevicius
}

READ PRIMARILY for her work as a writer and critic of fiction, Virginia Woolf was also a life-long essayist and critic of the essay. In 1903-twelve years before publishing a novel-she began her career as an essayist, writing, editing, and carefully binding a collection of literary essays about people, places, and events. ${ }^{1}$ In 1904 , her essays - portraits and other literary essays as well as cultural and literary criticism - began appearing in periodicals, where they would continue to be published throughout her life. In 1905, she wrote, "The peculiar form of the essay implies a peculiar substance; you can say in this shape what you cannot with equal fitness say in any other." 2

The following two essay sketches, published here for the first time, reflect Woolf's continuing attention, through her last decade, to the essay as a literary form. ${ }^{3}$ The first sketch, "Incongruous Memories," is from a June 1930 notebook that includes sketches for several literary essays and portraits, among them, "Evening Over Sussex," and portraits of Christina Rossetti and George Eliot. Woolf wrote it five years after publishing The Common Reader (a collection similarly concerned with the essay as imaginative literature), two years after Orlando (a work combining aspects of portraiture and fiction), and one year after A Room of One's Own. Two years later she published The Common Reader, Second Series and began The Pargiters, which she called, in her diaries, "an essay novel." In 1938, she published Three Guineas. Woolf did not date "Roger Fry: a series of impressions," but most likely wrote it between 1935 (when she delivered "Roger Fry") or 1936 (when she began reading for her book-length biography of Fry) and 1940 (when she published that biography). During this period, from 1928 to 1941, she wrote many other essays and sketches, among them "The Sun and the Fish," "Gas," "On Being Ill," "Leslie Stephen," six essays on London, and "Walter Sickert" (an essay that, like the Fry sketch, explores links between talk and portraiture, and between the observed and the imagined).

These two sketches discuss and demonstrate Woolf's aesthetic of the essay, especially the portrait essay, as she entered the last decade of her life. 
The essay, here, is not exposition, article, or debate, and the essayist no pretended objective observer. For truth, Woolf writes here, differs from "accuracy"; truth requires a merging of observation and imagination. And portraiture is where the remembered, seen, heard, and interpreted join. In these sketches, Woolf celebrates the portrait essay's fluidity and explores its peculiar ability to capture the truth of a life.

\section{Editor's Note ON THE TEXT:}

In editing these manuscripts, my goal has been to provide both a legible, revised sketch, and a sense of how Woolf thought about and worked through her aesthetic of the portrait essay. To preserve each of her deletions would make the texts very difficult to follow, for there are many crossouts - sometimes several in a single sentence. Thus, where deletions seem minor - a single word crossed out, or a phrase moved to a new location in the sentence-I have honored Woolf's revision without noting the change in the list of deletions. (For example, I offer only Woolf's revised sentence where she switched from "One day at some fair he saw a telescope" to "One day at some sale he found a telescope." There are almost a dozen such deletions.) In addition, I have corrected obvious mispellings, but left intact Woolf's characteristic idiosyncracies, such as peculiar punctuation, use of ampersands, and inconsistent use of apostrophes. Where Woolf has deleted a longer passage, and where the changes reflect her manner of thinking about portraiture, I preserve the deleted words and passages in the section labelled "Deletions." (There are twenty-four such deletions.) Bracketed numbers within the text mark their location in the manuscript and correspond to numbers in the Deletions section. Brackets also enclose words where Woolf's hand has been especially difficult to decipher, to indicate editorial judgment.

Woolf's revisions here are rich in implication. For example, in "Incongruous Memories," they indicate a shift from thinking of "inaccuracy" as a sort of accident, or as something that doesn't really matter, or as something a reader can never find out about, to a sense of inaccuracy as a kind of artistic statement $-a$ result of the words that are available. The changes also emphasize a kind of collaboration between writer and reader-both use imagination to discover "truth." Finally, the revision suggests that among literary forms, autobiography may be peculiarly suited to the kind of 
"truth" she describes as important, (it is available to "lesser" writers as well as to "august" ones). Revisions in the Fry sketch also celebrate the role of the imagination and collaboration (in this case, between writer and subject). As was her goal for The Pargiters, in each sketch, Woolf weaves together a passage focused on her aesthetic of the essay portrait with a demonstration of that aesthetic, a passage that makes a portrait.

Text (excluding introduction and editorial notes) copyright 1992 by Quentin Bell and Angelica Garnett. Reprinted by permission of Quentin Bell and the Henry W. and Albert A. Berg Collection, The New York Public Library, Astor, Lenox and Tilden Foundations. 
in congruour themonci.

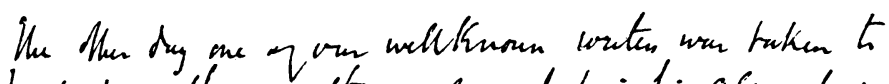

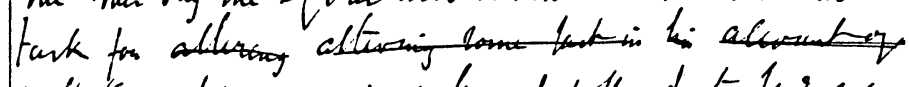

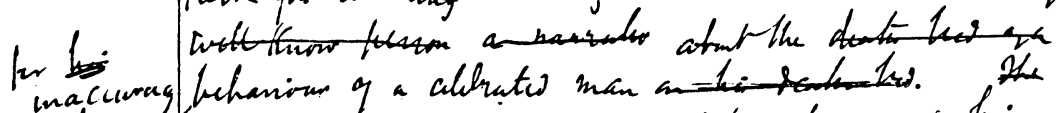

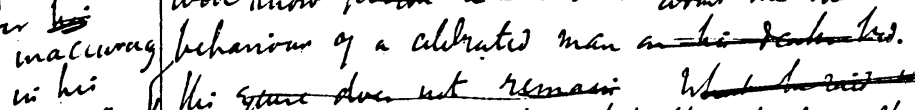

chicuristy.

lea 1 )

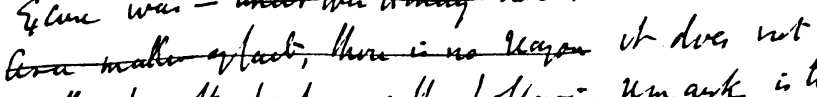

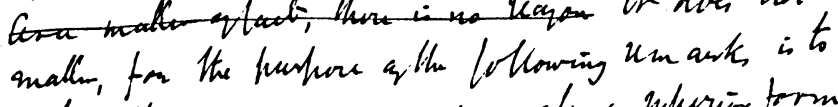
protut that macurray is hery ghim a enturior form. 7

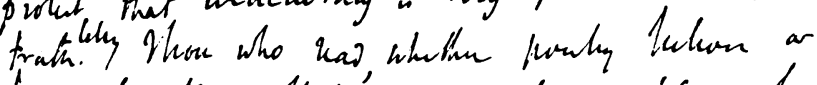
bropually, thow that zome wrabs or I Cenes have a heculiar hower to go an living, a porietly flowing,

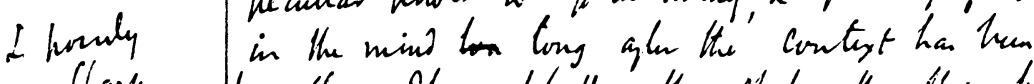

Chaygy. forgotter. They Whither the thathe they ithen fuet on

is the or forne, the helome tar savere

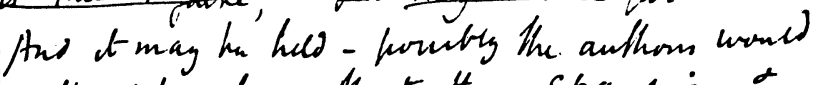
inthourtas cha - that there spansion o

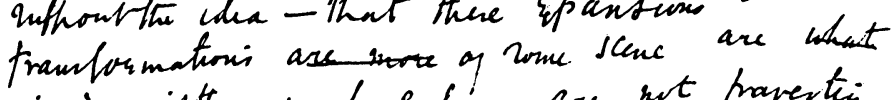

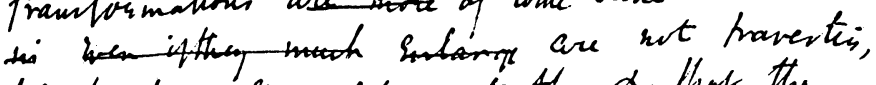
lut kegitimake destent the a that the

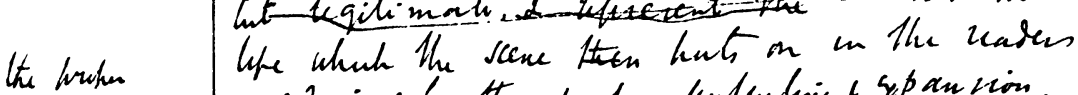
lefe whith mint is anly the hroter anfurling i spanvion, throud $\mathrm{t}$. hos.

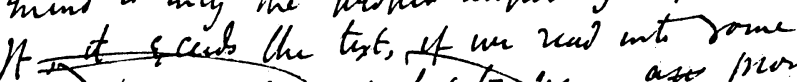

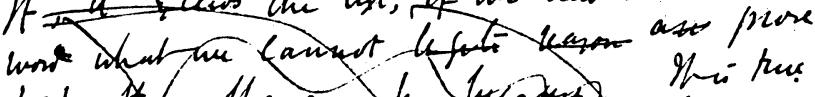

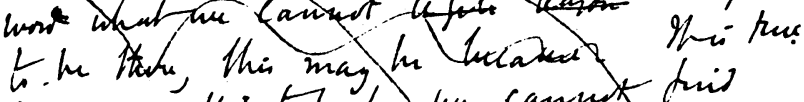
thon-4, calles thash, ame cannots forit proot on ow kearing Delone un-

126 


\section{INCONGRUOUS MEMORIES ${ }^{2}$}

The other day one of our well known writers was taken to task for [1] inaccuracy in his account of the death bed behaviour of a celebrated man. [2] His excuse was - [3] this or that. [4] It does not matter, for the purpose of the following remarks is to protest that inaccuracy is very often a superior form of truth. [5] Those who read, whether poetry, fiction or biography, know that some words or scenes have a peculiar power to go on living, \& possibly growing in the mind long after the context has been forgotten. [6] And it may be held-possibly the authors would support the idea-that these expansions $\&$ transformations of some scene are [7] not travesties, [8] $\&$ that the life which the scene puts on in the readers mind is only the proper unfurling \& expansion, [9] a natural process, [proved] by words when they are, for some reason highly charged with meaning. Clearly, a live scene will split, knock about in the mind, stir up others, [alter] memories perhaps, associations, [10] \& so form a further group which may be hardly recognisable when compared with the original. Yet, were the author there, \& could one present him with the effect that his words had, he might be the first to welcome the bastard \& to say that though he had not written all this out, this was what he meant-all this was implicit. Turgenev has a great power of this sort; Shakespeare of course; \& sometimes Jane Austin. [11] These august writers no doubt owe their suggestive power to supreme artistry - there they say, letting fall two or three words or making one phrase - that will do the trick; $\&$ so stop, leaving the reader to realise by degrees [12] that he has taken a charge of gunpowder into his head, which long after rolls its echoes along the hills and valleys of the soul. [13]

But far lesser writers, people of no artistry, no reticence, no great power over language, sometimes possess the same gift-especially in autobiography. On they plod with their narrative; \& nothing happens from page to page; then, for no reason, they summon up some scene [14] which begins at once to swell \& move \& float $\&$ is never afterwards to be dislodged, though it has in knocking about got mixed up with so much else that one would be sorry ever again to compare it with the original.

Here by way of sample is a scene of the kind-taken from what biography or autobiography scarcely matters. It appears in memory to run like this-There was, in the early part of the 19th Century, a certain farm 
house on the border of Scotland, [15] in which dwelt an elderly gentleman and his elderly wife, whose late marriage had been blessed by one son. They were very poor, $\&$ very proud; the last of their race, [16] which had now sunk into such decrepitude that only one wing of the old house was inhabited: the boy's name, perhaps was Henry. And, since he came to write his biography \& perhaps to occupy some post under a Victorian government, he was a boy of some initiative, ardour, \& longing for experience. At any rate while his father slumbered $\&$ his mother knitted in the quiet dying mansion, he would steal to the tower, [17] which by degrees he furnished barely enough, [but with] a bench and few books begged from his fathers study, which he would study there late at night under the stars.

There he would go, when the old people \& the two servants had gone to bed, \& read in folios \& quartos about Popes \& prelates; wars in [18] Hungary $\&$ all the ancient lore of the ancient world - about chemistry $\&$ astrology \& [then] about battles, policies \& dead men's doings - until he thought himself the only survivor in a world of the dead. Corpses. Many miles separated his fathers house from any other. The fields that used to be cultivated were now thick with weeds; the old roads were overgrown \& deep in winter mud. Life seemed to be ebbing away from them. In these circumstances, his thoughts turned naturally to the stars, which could be seen, through the tower window, in all their mystery. One day at some sale he found a telescope, the relict of a clergyman's library, \& bought it for some shillings, lugged it home-mounted it in the tower window. Now every night he swept the skies, \& noted one constellation after anothernamed them from his books, became acquainted with their glittering names $\&$ imagined the abysses through which he in his tower, \& the sleeping house, were sweeping so incessantly. He was in a fair way to have gone $\operatorname{mad} \&$ to have thought himself the only inhabitant of the glittering world.

But one day-it was midsummer, \& the light [19] bright in the sky the fancy took him to level his telescope at the earth. He got the focus of the distant hills - he could see the sheep moving on this side, here a rock, there a shrub. Lower he pointed it, upon a clump of trees. They glittered leaf by leaf. Again he lowered it. This time it rested upon a farm house-there were the vane, the door, the stocks glowing against the old grey walls $-\&$ then, suddenly, the disc [fastened aptly] upon two faces: a man, a woman; within that ring of intense visibility. Henry held them fast, \& saw them 
kiss: Miles away as it was, the shock was tremendous. There was life, love, [power]. Sweeping his telescope aside, he crushed his hat on his head and rushed downstairs along the road into the world - to become in process of time - was it Sir Henry Taylor of the Colonial Office? It may have been all the rest is forgotten. ${ }^{5}$

\section{ROGER FRY: A SERIES OF IMPRESSIONS ${ }^{6}$}

In writing these impressions I have not aimed at accuracy of date or fact. I have tried to make a portrait of Roger Fry almost as a novelist might make a character in fiction. I have taken this course partly through inability to deal with his work from a critical point of view; and partly because he himself once [1] offered to sit for a portrait. He was to talk about himself, and I was to take notes and write a [2] life in which fiction was to be allowed full play - the idea being that it was only by having full liberty to invent and create that a true life could be written. Unhappily the sittings never took place; I have nothing but memory to depend upon; so that the portrait is merely an impressionist sketch written in the hope that it may serve a more serious biographer.

I

Many years ago two figures, a man and a woman, strolled in a garden on the banks of the Cam. Both were tall, there was a distinguished look about them. It was natural to ask, as they came by, Who are those people? "Roger Fry and his wife" was the answer. It was a summer afternoon, and the two figures seemed for a moment to connect themselves with the beauty of the flowers and the willows and the sliding river. Next moment the picture had vanished.

The name Roger Fry however, insensibly gathered a certain meaning in the course of the next few years. In those quiet days before the war there was always somewhere in the background a little group of people who got up lectures, wished to revive ancient musical instruments, supported classical concerts, withstood the current taste in dress and furniture, and collected eighteenth century chairs and tables. Roger Fry-his name that is, - seemed to be among them. When a circular, printed on hand made 
paper, announced a series of lectures on early Italian Art would be held at five thirty in Leighton House, it seemed fitting that Roger Fry should be the lecturer. His name suggested rows of people sitting soberly listening to some 'course' or other; and also it suggested very discreet water colour paintings, with one brown cow or one white sheep precisely in the right place; or an oil painting of a swan sailing on a lake, while a youth stretching over dabbles his hand in the placid waters. It seemed to be essential in those days if you cared for art, to dislike the present; to be perpetually occupied in trying to get back to a more austere and more peaceful age, when furniture was made by hand, an age when things were handmade, and dignified and rightly placed. Roger Fry was accepted by that world; and it seemed then that there was no reason why that world should not go on forever, [3] the two worlds, of art lovers and philistines should not exist side by side each going its own way and ignoring the other.

Those were the associations that made the name of Roger Fry dim and respectable.

Roger Frys name had become rather dim and quiet. [4]

But ...

Those three dots are a tribute to human weakness. When a whole conception is swept away and another substituted, the mind is so jumped out of its bearings that it is incapable of observation. Of course there must have been a gradual transition; he must have worn some tie, and have looked in this way or in that; but all these details have been obliterated, by a series of impressions, chiefly of colour by one single impression - the room [5] had changed. Strictly speaking this was true. The chairs and tables were strewn with patterns of cotton made in Manchester for the natives of Africa. Propped up against the walls were pictures of chrysanthemum in pots which seemed to flare away like roaring fires of red paint. Then there was a still wet canvas, depicting Christ standing on his head; and a portrait of a lady whose left cheek was composed of a cheque upon which figures were still legible. Also there were several rough yellow white pots and hats worn by negresses made of black and white straw.

Where was the gentle Don who had lectured on Cimabue in Leighton House? He was nowhere. And what there was in his place was something so complex, so disturbing, so many sided, that it is tempting to poach on the novelists preserves and to say that Roger Fry had become, been trans- 
formed into a don Quixote; into a wildly fantastica knight, prancing on across the prospect hung with the queerest assortment of old tins and frying pans and chains - such as he looked once at a childrens party, where he came dressed up at a cost of three and nine pence at Woolworths shop. There was something ridiculous laughable extravagant wildly amusing in the transformation that he made. Watts paintings vanished; Van Gogh took his place. Queen Anne chintz were overhung with African cottons. Superficially it was a source of constant shouts of laughter. It was like watching a pageant; standing in the street and cheering on the fantastic procession.

But no one was allowed to remain an outsider for long. For one thing, after the first shock and the amusement and the surprise and the laughter, his seriousness was apparent. And then again, the attack left art proper, and turned upon literature. It was then not so easy to stand outside and laugh. The method of his approach was by way of a little French book that had just appeared-Marie Claire by Marguerite Audoux. Soon that book was in everybodies hands. "D'you mean to tell me youve not read it? Ive already given away twenty copies but heres another." The book is now forgotten. But the discussions which it brought about still reverberate. For Marie Claire illustrated the fact that literature was affected by the same disease as painting. We writers were circling vaguely in the old eddies. We were using old cliches. We were using far too many adjectives. That was the line of the indictment. That led to frequent recourse to the bookcase. Dante was the supreme poet, not Shakespeare. Wordsworth was the greatest of the moderns. Shelley was convicted. Keats was suspected. And he set to work with a pencil upon modern poets and novelists; underlined their useless adjectives, their merely literary phrases. All that was 'dim', romantic, all that echoed and reverberated was abhorrent.

\section{Notes}

1. A version of this collection is included in A Passionate Apprentice, Mitchell A. Leaska, ed., NY: HBJ, 1990.

2. The Essays of Virginia Woolf, Volume 1, Andrew McNeillie, ed., NY: HBJ, 1986, page 25. 
3. While they contain images and scenes that occur in other works (see notes 4 and 6 below), these essay sketches stand out for the way Woolf uses them. Here, the scenes capture her aesthetic of the portrait essay-she talks about the use of imagination in portraiture as she demonstrates its use.

4. "Incongruous Memories" is from a holograph notebook dated June 1930, and labelled, "Articles, essays, fiction, reviews Volume IV." A version of its telescope scene appears in her story "The Searchlight" (see $A$ Haunted House and Other Stories or The Complete Shorter Fiction of Virginia Woolf, edited by Susan Dick.) Versions of the scene also appear in various notes and sketches including "Ghosts" (in The Complete Shorter Fiction).

5. See The Autobiography of Henry Taylor, Volume 1, Henry Taylor, London: Longmans, Green \& Co., 1885, especially, pp. 45, 46, and 73.

6. "Roger Fry: a series of impressions" is an undated typescript with Woolf's holograph corrections. While it bears little resemblance to "Roger Fry" (see The Moment and Other Essays), a version of some scenes appear in her book-length biography of Fry. The sketch alone focuses on the role of the imagination (and talk) in portraiture.

\section{DELETIONS}

The numbers preceding the following words and passages correspond to the numbers enclosed by brackets within the printed text above, and indicate where the deletion occurs in Woolf's manuscript. The deletions are preserved here as they appear in her papers - whether a single word, an incomplete word, a series of words that seem unconnected, or a full or unfinished sentence. Also bracketed here, as in the printed text above, are individual words especially difficult to decipher and a few editorial comments.

\section{Deletions from "Incongruous Memories"}

1. altering altering some last in hi account of a well known person a narrati about the death bed of a

2. on his death bed. The His excuse does not remain What he said in his excuse, does not matter-but the fact 
3. whatever it may have been.

4. As a matter of fact, there is no reason

5. [An indecipherable word (possibly "telling") appears above and to the right, with no line indicating its precise placement.]

6. They Whether the shape they then put on is true or false, Often they become far more

7. what is even if they much enlarge

8. but legitimate, $\&$ represent the

9. It, it exceeds the text, if we read into some word what we cannot legiti reason as prove to be there, this may be because It is true that if, called to task, we cannot find proof of our reading before us -

[Also, in the nearby left margin, without indicating where she would have it placed, Woolf has written: the proper life which should be lived.]

10. other ideas peculiar to the thinker - so that at last he finds himself believing that

11. But these august authors are too august to be trifled with.

12. the curious power of the unsaid.

13. What is odd, however, is

14. make some little

15. Life was incredibly silent $\&$ lonely for the boy who lived there with his elderly parents. They were decayed gentlefolk trying to

16. [In the nearby left margin, without indicating where she would have it placed, Woolf has written: On the outskirts stood one of those peile towers wh.]

17. where he had made himself a study full of such books as he could borrow or perhaps buy cheap at country sales. This youth met with no [response]. The

[While Woolf's deletion lines do not cover this entire passage, her manner of drawing in those lines along with the sense of the passage indicate that she meant to delete all of the words included here.]

18. Arabia 
19. [Here, Woolf has deleted the word "was" and written in "of the," without integrating it into the text.]

\section{Deletions from "Roger Fry: a series of impressions"}

1. suggested that we should collaborate in a life of him. [Only partially crossed out. Also, in the nearby left margin, without a line indicating its placement, Woolf has written: to be the subject in a biographical experiment.]

2. biography that was half fiction [Only partially crossed out. Also, there is a faint line through part of the sentence following this deletion. While the line appears to be a slip of the pen, it is possible that Woolf considered deleting the part of the sentence following the em-dash as well.]

3. [Here, Woolf has typed two different endings for this sentence without indicating which she preferred. With the assumption that she reconsidered what she had first written, I have provided the second ending in the printed text. The ending she typed first is: existing side by side with the world that cared nothing for art; each held its own way in ignorance of the other.]

4. Therefore it was a considerable surprise, some time about 1911 to meet Roger Fry for the second time in the flesh. There he was, the man who had walked in the garden that summer - the man who had spent the intervening years lecturing at Leighton House on Italian art - But, in one second, in the time it took to open a door and come into a room, all those associations, all those preconceptions were torn up. It is not strange therefore that

5. [I have left intact Woolf's apparently inconsistent statement that it was series of impressions and a single impression, as she made no deletions or corrections to it. However, in the case of this sentence's ending and the complete sentence that follows, Woolf does show evidence of revision, but without making a definitive choice between two options. In the printed text I have provided the words Woolf typed in just above the original manuscript, with the assumption that she reconsidered what she had first written. I have deleted the following: is entirely different. In a material sense this was true.] 